\title{
Attila DUDÁs* \\ Legal Frame of Agricultural Land Succession and Acquisition by Legal Persons in Serbia**
}

\author{
Abstract
}

The rules on the succession and transfer of agricultural land in Serbia may be characterised as liberalistic. There are no special inheritance regimes applicable specifically to the succession of agricultural land. There is only the possibility of an heir, engaged in agricultural production, to request that the court name bim the sole heir of the agricultural land, with the obligation to compensate others. Similarly, the transfer of agricultural land by inter vivos transaction is also essentially devoid of any serious legal restrictions, either for natural persons or for legal entities. There is no cap on the acquisition of ownership, nor must the buyer prove that he or she is, in fact, engaged in agricultural production. Serbian law excludes the possibility of foreign persons or legal entities acquiring ownership of agricultural land. According to the Stabilisation and Association Agreement concluded with the European Union, it was expected that Serbia would gradually enable natural persons and legal entities from the member states of the EU to acquire ownership of agricultural land by no later than 1 September 2017 when the four-year period for the implementation of this obligation expired. Seemingly, in order to fulfil the obligation, the Serbian National Assembly amended the Law on Agricultural Land in August 2017. The amendments explicitly regulate under which conditions natural persons and legal entities from the EU may acquire ownership of agricultural land. However, even a superficial reading of the new regulation reveals that the opposite effect has been achieved. Instead of enabling natural persons and legal entities from the EU to obtain ownership of agricultural land on equal footing with domestic natural persons and legal entities, the legislature created a set of special conditions applicable only to the former but not to the latter. Moreover, the conditions are so strict that no legal entity could meet them, while natural persons only hypothetically could, if at all. Therefore, it seems that the 2017 amendments to the Law on Agricultural Land hardly aimed to implement the Stabilisation and Association Agreement.

Keywords: agricultural land, agricultural holding, family farm, acquisition of ownership by legal entities, acquisition of ownership by EU nationals.

Attila Dudás: Legal Frame of Agricultural Land Succession and Acquisition by Legal Persons in Serbia. Journal of Agricultural and Environmental Low ISSN 1788-6171, 2021 Vol. XVI No. 30 pp. 59-73, https://doi.org/10.21029/JAEL.2021.30.59

* Ph.D., Associate professor, Faculty of Law, University of Novi Sad, Serbia, a.dudas@pf.uns.ac.rs

** This paper comprises the results of research carried out within the confines of the scientific projects Biomedicine, Environmental Protection and Law (No. 179079) and Development of the Methods, Sensors and Systems for Monitoring Quality of Water, Air and Soil (No. III 43008) of the Ministry of Science and Education of the Republic of Serbia.

The research of this article was supported by the Ferenc Mádl Institute of Comparative Law.

https://doi.org/10.21029/JAEL.2021.30.59 


\section{Registration of agricultural farms/holdings}

The basic statutory act that regulates agriculture in Serbia is the Law on Agricultural Production and Rural Development. This law distinguishes different categories of persons that may be engaged in agricultural production. The broadest category is agricultural holding/agricultural farm (Serb. poljoprivredno gazdinstvo), which is defined as a production unit in which a company, agricultural cooperative, public institution or other legal person, private entrepreneur, or individual agricultural producer maintains agricultural production. ${ }^{1}$ The family agricultural holding or, simply, family farm (Serb. porodicno poljoprivredno gazdinstvo) is a subtype of agricultural holding, where an individual agricultural producer together with the members of his or her household maintains agricultural production. ${ }^{2}$ The family farm must have its representative or holder (Serb. nosilac), which is defined in the law as a natural person who is an individual agricultural producer or an entrepreneur maintaining agricultural production and registered as such in the registry of agricultural farms. ${ }^{3} \mathrm{~A}$ member of the family of the holder of a family farm is also defined by the law: an adult member of the holder's household who is regularly or occasionally engaged in the agricultural holding and is, as such, registered in the registry upon his or her statement. A minor member of the holder's household becomes a member of the family agricultural holding upon the statement of consent of his or her parents or statutory guardian, respectively. ${ }^{4}$

The law differentiates two types of family farms based on their economic power: commercial and non-commercial holdings. A commercial family farm is marketoriented, while a non-commercial farm is non-market oriented and the representative of which is a beneficiary of the agricultural pension scheme. ${ }^{5}$

The agricultural holding itself does not have the status of a separate subject of law; that is, it does not have its own juridical personality. Hence, it is not a separate subject of tax obligations or the obligation to pay contributions to mandatory social insurance. ${ }^{6}$ The subject of tax and social security contributions is the legal person who registered the agricultural holding or the natural person or entrepreneur as the holder of the holding, respectively.

The pension of the natural person, being a holder or member of a family farm, depends on the contribution of the mandatory social insurance that they have paid in or that has been paid in by the legal entity on behalf of which the natural person acts. This means that the obligation to pay the contribution does not depend on the existence and registration of agricultural holdings.

\footnotetext{
${ }^{1}$ Law on Agriculture and Rural Development, Art. 2, s. 1, 4).

2 Ibid. Art. 2, s. 1, 5).

${ }^{3}$ Ibid. Art. 2, s. 1, 6).

${ }^{4}$ Ibid. Art. 2, s. 1, 7).

${ }^{5}$ Ibid. Art. 16.

${ }^{6}$ On different aspects of the taxation of agricultural production, see Milošević et al. 2020, 6-12.
} 


\section{Transfer of agricultural holding/family farm}

Agricultural holdings cannot be transferred as such. Registering an agricultural holding does not affect ownership rights over the land: the owner of the land remains the subject of law, a natural or legal person that established and registered the holding. This means that the land, which is registered under a given agricultural holding, may be transferred as a matter of course by inter vivos transactions, under the general rules of civil law, via a contract concluded by their owner, that is, by the natural or legal person.

The only exception to non-transferability of the agricultural holding itself is envisaged by the Ministerial Decree on entry in the Registry of Agricultural Holdings and Renewal of Registration, as well as on the Conditions for Passive Status of Agricultural Holdings, and only with respect to registered family farms. ${ }^{7}$ It prescribes the possibility that the members of a registered family farm, in case of the demise of its nominated holder, can request the registry of agricultural holdings to have the farm transferred to one of its members elected by the members of the family farm, that is, to request to have him or her registered as the nominated holder of the family farm, without losing the identity of the farm (registration number, address, banking accounts, etc.).

Establishing or dissolving an agricultural holding has no effect on the ownership and leasehold rights of its members. In establishing an agricultural holding, the holding does not become the owner of the land of its members.

\section{Succession of agricultural land on grounds of dissolution of marriage or family household and on grounds of inheritance}

Family farms in Serbia are not recognised as subjects of law in terms of proprietary relations or marital and inheritance law. However, the law takes into consideration that there may be situations in life in which spouses or members of the same household live and acquire property together, but the property is regularly registered under the name of one person, usually the husband in the case of a simple family, or, in the case of an extended family, most often, the eldest male member of the household. This practice is most common in families in rural areas, where many generations live and work on the family estate together, accumulating wealth and acquiring new tiles of agricultural land. The convoluted perplexity of legal relationships between spouses, partners in common-law marriage, or members of family households becomes legally relevant when the marriage, common-law marriage, or household dissolves, or one or more members wish to leave it. There are three statutes in Serbian law that offer rules applicable to such situations. First, the Law on the Basis of Ownership and Proprietary Relations prescribes that a special form of joint property (joint property with undivided but, if need be, divisible shares of the joint owners) may exist if envisaged by a special law. ${ }^{8}$ This form of ownership with a plurality of owners should be distinguished from co-ownership, in which the share of each co-owner is precisely determined.

\footnotetext{
${ }^{7}$ Ministerial Decree, Art. 4, s 2. and 3.

${ }^{8}$ Law on the Basis of Ownership and Proprietary Relations, Art. 18.
} 
Attila Dudás

Legal Frame of Agricultural Land Succession and Acquisition by Legal Persons in Serbia
Journal of Agricultural and

Environmental Law

$30 / 2021$

The special law in this regard is the Family Act, which offers rules applicable to several situations in which more people, closely related one to another, live in the same household and acquire assets jointly, but the real estate is usually registered only under the name of one of them. Most typically, this happens with spouses in the case of marriage and partners in common-law marriage. They live in the same household and acquire assets together, but the assets, especially real estate, are usually registered under the name of only one of them, most commonly that of the husband or male partner, respectively. The basic tenet of Serbian patrimonial law is that spouses acquire assets in joint matrimonial ownership. This applies to all assets acquired by work (including all types of work, even household activities). ${ }^{9}$ The exclusive property of spouses comprises the property they had already owned before the marriage was concluded as well as the assets they acquired during the marriage gratuitously (by testament, donation, etc.) or by the dissolution of joint matrimonial property. ${ }^{10}$ To protect the party with the weaker position in the marriage, typically the wife in rural areas, the Family Act prescribes a presumption that all real estate registered under the name of one spouse is considered joint matrimonial property, even if only one of them appears as the sole owner in the Real Estate Registry. ${ }^{11}$ All of these rules are appropriately applicable to partners in common-law marriages as well ${ }^{12,13}$. The dissolution of joint matrimonial property may have a serious impact on ownership and the right to use agricultural land. Upon the dissolution of the marriage, the spouses will acquire a divided co-ownership, usually in equal shares, regardless of whether they are both engaged in agricultural production. The co-ownership between a spouse who is an agricultural producer and one who is not distorts the efficient functioning of ownership rights, thus restraining the transfer or use of agricultural land. This caveat has been taken into account in the Family Act, which prescribes that in the case of dissolution of joint matrimonial property, each spouse may request that the court establish his or her exclusive ownership over assets that are required for their profession or trade on the account of their share in the joint matrimonial property. ${ }^{14}$ This means that the court will compensate the other spouse by granting exclusive ownership or a higher ownership share in other assets constituting joint matrimonial property. The Act refers only to assets required for conducting a trade or profession. It does not explicitly name agricultural production. However, there is no reason that agricultural production would not qualify as a trade or profession in this respect.

The complex proprietary relationship between spouses becomes even more complicated when members of their narrower or wider family participate in the acquisition of property.

\footnotetext{
${ }_{9}^{9}$ Family Act, Art. 171.

${ }^{10}$ Ibid. Art. 168.

${ }^{11}$ Ibid. Art. 176, s. 2.

12 Ibid. Art. 191.

13 At present, there is no civil union or registered partnership in Serbia, only the traditional common-law marriage alongside the regular marriage. A common-law marriage under the Serbian Family Act exist if a man and a woman who are not in marriage but between whom there are no obstacles for concluding one, live in lasting matrimonial-like community. Family Act, Art. 4, s. 1.

14 Family Act, Art. 184.
} 
Until the $19^{\text {th }}$ century, it was very common in the history of Serbian (and most South Slavic) nations that people lived in so-called extended family groups or extended family communities (Serb. porodicna zadruga, Ger. Hauskommunion), in which more families linked by kinship lived and worked together, predominantly making their living from agriculture. In the extended family group, the proprietary relationships were largely regulated by customary $\operatorname{law}^{15}$ and were hallmarked by the inferior legal position of female members ${ }^{16}$.

Although extended family groups gradually disappeared in the $19^{\text {th }}$ century, the tradition of living and accumulating wealth together in wider family groups outlived them to some extent. For this reason, the Family Act prescribes that assets acquired through work by spouses or partners together with other members of their family household during the time when they lived together in that household represents their joint property. ${ }^{17}$ Blood relatives, relatives by marriage, and adoptive relatives of the spouses or partners who live with them in the same household are considered members of a family household. ${ }^{18}$ The Family Act prescribes the appropriate application of rules pertaining to the proprietary relations between spouses, except for the rules on the registration of ownership in the registry of real estate and the presumption of equal shares of the members of the household in joint ownership. ${ }^{19}$ With respect to all legal relationships arising between the members of the household that are not governed by the Family Act, the Act prescribes the appropriate application of the rules of the Law on the Basis of Ownership and Proprietary Relations and the Law of Obligations. ${ }^{20}$

A similar position has also been adopted in the Law on Inheritance. There is no special set of rules pertaining to the inheritance of agricultural land in the Law on Inheritance in the sense of a special intestate inheritance regime applicable to the succession of agricultural land. However, the law considers that, in the case of succession of agricultural land, not all heirs might be interested to the same degree to use it for agricultural production. Therefore, it prescribes that upon the request of an heir who lived in the same household with the deceased, the court may decide, if it finds it appropriate, that certain assets or groups of assets and rights are to be inherited by that one heir, which would otherwise belong to others. On the other hand, the court obliges that one heir to reimburse those others for the value of such assets or rights, within a deadline determined by the court in light of the circumstances of the given case. ${ }^{21}$ Until the reimbursement of their value, the other heirs have a statutory lien on the assets and rights inherited by the heir who lived in the same household as the deceased. ${ }^{22}$ If the heir fails to pay the reimbursement by the deadline determined by the court, the other heirs may request payment or a transfer of assets and rights that they

\footnotetext{
${ }^{15}$ Kulauzov 2010, 281-289.

${ }^{16}$ Kulauzov 2008, 807-816.

${ }^{17}$ Family Act, Art. 195, s. 1.

18 Ibid. Art. 195, s. 2.

${ }^{19}$ Ibid. Art. 195, s. 3.

20 Ibid. Art. 196.

${ }^{21}$ Law on Inheritance, Art. 232, s. 1.

22 Ibid. Art. 232, s. 2.
} 
would otherwise inherit. ${ }^{23}$ This general regulation applicable to numerous types of assets and rights is further enforced by a separate regulation applicable only to agricultural land. The law, namely, prescribes that if the inheritance comprises agricultural land, the court is obliged to warn the agricultural producer who lived together in the same household with the deceased that he or she is entitled to request to have his or her inheritance of ownership of the agricultural land declared. ${ }^{24}$ The succession of agricultural land between family members is further supported by tax regulations. The Law on Property Taxes envisages a tax exemption for inheritance or donation if the heir in the second order of succession or the donee, who would, in the case of inheritance, belong to the same order of succession, is engaged in agricultural production if they inherit or receive as a gift the property serving farming purposes for them and if they have lived with the decedent or donor in the same household for at least one year prior to the decedent's death or receiving the gift, respectively. ${ }^{25}$

The succession of ownership of agricultural land is thus accomplished in two steps. The first is to divide the joint property between spouses or partners or members of the extended family if there is such property. Once any joint property has been divided by the application of the rules of the Family Act, the agricultural land constituting the bequest may be transferred to the heir who lived together with the deceased and is engaged in agricultural production according to the rules of intestate succession of the Law on Inheritance.

Aside from the rules of intestate succession, the Law on Inheritance provides broad freedom of the testator in terms of disposition over their assets at their best consideration. The only restriction in respect of the freedom of testamentary disposition is the rules of compulsory share of inheritance. Heirs who are the descendants and the spouse of the testator would acquire half of the share under the regime of intestate succession, while other heirs would acquire one third. Taking into account the perplexity of legal relationships that may arise between the heirs, it is prudent for the testator to allocate by testament the agricultural land to heirs who are already engaged in agricultural production or have the best prospects to do so.

The registration of ownership, acquired by inheritance, is conducted by the court or a public notary. Once the competent organ delivers the inheritance degree, the registration of title in the Real Estate Registry is accomplished ex officio. There is no ownership limit for agricultural land with respect to domestic natural persons or legal entities.

\section{Transfer of agricultural land by contract}

\subsection{General rules on the transfer of agricultural land by contract}

As it is commonly accepted in European civil law systems, particularly in countries following the traditions of Austrian law, in general, a contract alone is not capable of transferring ownership. It is merely the valid legal ground (iustus titulus) of

${ }^{23}$ Ibid. Art. 232, s. 3.

${ }^{24}$ Ibid. Art. 233.

${ }^{25}$ Law on Property Taxes, Art. 21. sec. 1. subsection 2). 
the acquisition of ownership, based on which the means of acquisition (modus acquirendi) must also be accomplished. With respect to agricultural land, as is the case with all real estate, the means of acquisition is the registration of the ownership of the buyer in the Real Estate Registry. This system of acquisition of ownership is commonly denoted as the titulus-modus system. ${ }^{26}$ However, it is not being implemented clearly and consistently in Serbia, in some cases due to the conclusion of contract and in others because the possession of the real estate determines whether the buyer acted in good faith, which is also a condition of acquiring ownership. ${ }^{27}$ Regardless of its distortions, the system could still be considered a sort of titulus-modus system or, at a minimum, a mixed system that is predominantly based on the logic of titulus-modus.

The conditions of the validity of contracts aimed at the conveyance of real estate are set out in the Law on the Transfer of Real Estate and partially in the Law on Public Notaries, which are considered exceptional in relation to the general rules of contract law envisaged by the Law on Obligations. The Law on the Transfer of Real Estate prescribes that all contracts aimed at the conveyance of ownership of real estate, including agricultural land, must be concluded in a strict from of a notarial deed, specifically in a form of notarial solemnisation. ${ }^{28}$ Failing to comply with the requirement concerning the form results in the nullity of the contract. ${ }^{29}$

Solemnisation or notarial confirmation of a contract means that parties draft the text of the contract (or have an attorney prepare it for them), and the notary public reads it out to the parties at a hearing. If the parties confirm the text of the contract as read out by the notary public, they sign it, and the notary issues a certificate of confirmation, which is to be attached to the contract signed by the parties. Solemnisation is, therefore, more than a simple certification of signatures of the parties but less than a notarial deed in the narrow sense, whereby the notary him- or herself prepares the text of the contract. After the conclusion of the contract, the notary public ex officio sends its copy in electronic form to the competent tax authority ${ }^{30}$ and to the court administering the registry for contracts of transfer of real estate ${ }^{31}$. In addition, the notary public ex officio sends to the Real Estate Registry the request for the registration of the title of the buyer. ${ }^{32}$

The most important peculiarity of the sale of agricultural land, in contrast to other real estate, is that the Law on the Transfer of Real Estate envisages a statutory right of pre-emption. The pre-emption right in relation to agricultural land has a long tradition, not only in Serbia but in other countries that belonged to the former Yugoslavia as well. ${ }^{33}$ The topicality of the need to restrict the free market for agricultural land using a right of pre-emption is supported by the fact that Hungary

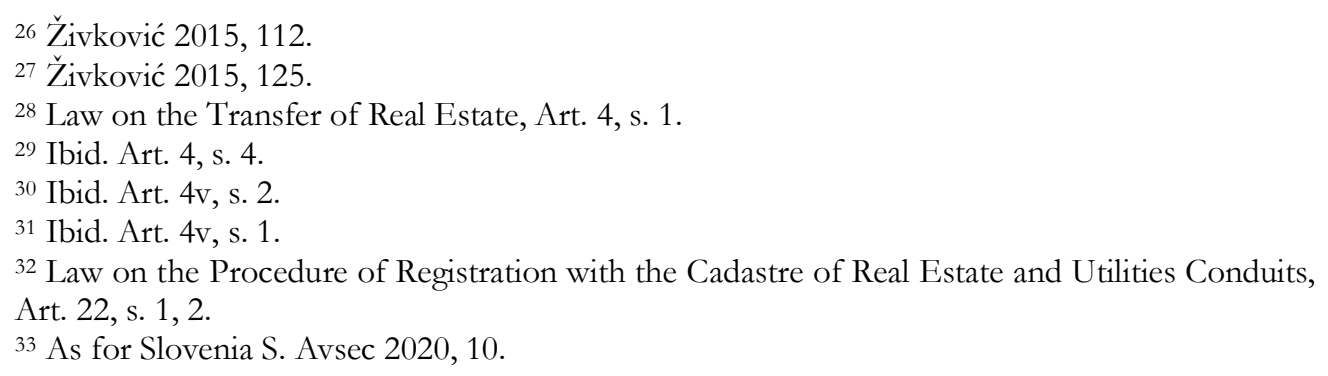


recently introduced rules that are, in comparison to Serbian legislation, much more nuanced and elaborate. ${ }^{34}$

The owners of neighbouring lots have a pre-emptive right if the owner of agricultural land decides to sell it. ${ }^{35}$ The owner is obliged to make an offer to the owners of all neighbouring lots. ${ }^{36}$ The offer has to be made in writing, contain all terms of the prospective sale ${ }^{37}$, and be sent by registered mail ${ }^{38}$. The beneficiary of the right of pre-emption has 15 days to accept or reject the offer. ${ }^{39}$ The acceptance of the offer is likewise to be sent by registered mail to the seller. ${ }^{40}$ If the beneficiary fails to notify the seller in time and by the means envisaged by the law or does not react to the offer in any way, the seller is entitled to sell the agricultural land to any third party, but not under more favourable terms. ${ }^{41}$ If the seller fails to notify the owners of the neighbouring lots or does so in infringement of the aforementioned procedure, the beneficiary may request the court to have the contract with the third party declared ineffective towards him or her and transfer the ownership to him or her under the same conditions. ${ }^{42}$ The beneficiary may exert this right within two years from the day of the formation of the contract and within 30 days from the day he or she gained knowledge thereabout. 43 The major shortcoming of these rules is that the parties, especially the seller, are not obliged to prove in the process of formation of a contract for the notary public that the beneficiaries of the right of pre-emption have been duly notified. Moreover, the notary public has no authority to determine whether the beneficiaries have actually been notified. He or she will merely state in the confirmation of solemnisation that a pre-emptive right exists because the object of the sale is agricultural land. Therefore, the existence of a right of pre-emption is a contractual risk for the seller, that is, the owner of the agricultural land, and the third-party buyer, but it does not preclude the formation of a contract nor the transfer of the title in the Real Estate Registry. The parties simply need to 'wait out' the time limits of two years and 30 days, respectively, as when they expire, the sale, regardless of the infringement of the right to pre-emption of the owners of the neighbouring lots, becomes legally perfect.

\subsection{Acquisition of agricultural land by domestic and foreign legal persons}

The Law on the Basis of Proprietary Relations sets out no special requirements for domestic legal persons with respect to the acquisition of agricultural land based on contract.

\footnotetext{
34 See for example Olajos 2017, 92.; Raisz 2017, 68-74; Csák \& Szilágyi 2013, 215-233; Szilágyi et al. 2019, 40-50, etc.

${ }^{35}$ Law on the Transfer of Real Estate, Art. 6, s. 1.

${ }^{36}$ Ibid. Art. 6, s. 2.

${ }^{37}$ Ibid. Art. 7, s. 1.

38 Ibid. Art. 7, s. 4.

39 Ibid. Art. 7, s. 3.

40 Ibid. Art. 7, s. 4.

41 Ibid. Art. 8.

42 Ibid. Art. 10, s. 1.

${ }^{43}$ Ibid. Art. 10, s. 2.
} 
All domestic subjects of law, being natural or legal persons, may acquire ownership of agricultural land without any restrictions. There is no cap envisaged in the acquisition of agricultural land or special duties applicable only to legal persons.

The situation is rather different with respect to foreigners. Under the Serbian Constitution, foreign nationals are considered equal to domestic citizens in terms of acquisition of rights and performance of duties unless there is an exception provided by the Constitution or a statute. ${ }^{4}$ Such an exception is prescribed by the Law on the Basis of Proprietary Relations. It sets out a different regime of acquiring the ownership of real estate by foreign nationals. In general, these rules pertain to all types of real estate. There are no special rules pertaining to agricultural land in this statute. It prescribes that a foreign natural or legal person conducting activity in Serbia may obtain ownership of real estate, provided reciprocity exists and that the real estate is necessary for the activity they conduct in Serbia. ${ }^{45}$ Both conditions, namely the existence of reciprocity with the state from which the foreign natural or legal person has nationality and the requirement that the real estate is necessary for conducting their activity in Serbia, must be fulfilled and proven in each individual case. The law prescribes that special rules excluding foreign nationals from acquiring ownership of real estate may be introduced by special statutes pertaining only to specific areas of Serbia. ${ }^{46}$ A contract by which ownership is transferred onto foreign nationals could be confirmed by the notary public only when the aforementioned conditions are fulfilled. ${ }^{47}$ The Ministry of Justice provides information on whether reciprocity exists with the state of foreign nationals' nationality. The fulfilment of the other requirement, that is, that the real estate is necessary for the legal entity's activity in Serbia, is to be determined by the Ministry of Commerce. 48

Before one rushes to a conclusion from the labyrinthine logic of the Law on the Basis of Proprietary Relations that foreigners may acquire ownership of agricultural land, if it is required for their activity in Serbia, the Law on Agricultural Land shortcircuits this riddle. It explicitly states that no foreign natural person or legal entity may acquire ownership of agricultural land except for EU nationals under the terms prescribed by the same statute or by the Agreement on Stabilisation and Association. ${ }^{49}$ Therefore, non-EU foreign natural or legal persons cannot obtain ownership of agricultural land in Serbia.

\footnotetext{
${ }^{44}$ Constitution of the Republic of Serbia, Art. 17.

${ }^{45}$ Law on the Basis of Proprietary Relations, Art. 82a, s. 1.

46 Ibid. Art. 82a, s. 2.

${ }^{47}$ Ibid. Art. 82v, s. 1.

${ }^{48}$ Ibid. Art. 82v, s. 4.

${ }^{49}$ Law on Agricultural Land, Art. 1, s. 4.
} 


\subsection{Acquisition of agricultural land by EU nationals}

As in all countries in the process of accession to the European Union, ${ }^{50}$ the question of enabling natural and legal persons from the European Union to obtain ownership of agricultural land became one of the most debated issues in Serbia. The negotiations with the EU began in 2005, and the Stabilisation and Association Agreement was concluded in 2008; it entered into force on 1 September, 2013, after the necessary approvals and ratifications had been obtained. ${ }^{51}$ The Agreement prescribes the duty of the Republic of Serbia, as from the entry into force of the Agreement, to authorise, by making full and expedient use of its existing procedures, the acquisition of real estate in Serbia by nationals of member states of the European Union. The Agreement obliges Serbia to progressively, within four years from the entry into force of the Agreement, adjust its legislation concerning the acquisition of real estate in its territory in order to ensure nationals of the member states of the European Union the same treatment as compared to its own nationals. ${ }^{52}$

Just before the expiry of the mentioned period of four years, on 28 August, 2017, the Serbian National Assembly adopted amendments to the Law on Agricultural Land, the aim of which was to implement the aforementioned article of the Agreement. The legislator inserted a new article ${ }^{53}$ into the text of the statute, which seems more to limit than to enable EU nationals to acquire ownership of agricultural land. It applies to all cases of obtaining ownership based on contract, be they onerous or gratuitous. ${ }^{54}$

An EU national may acquire ownership of agricultural land in Serbia under the following conditions: (1) He or she must reside in the territory of the same municipality in which the agricultural land is located; (2) must cultivate that same land for at least three years; (3) must have a registered family farm in Serbia without interruption for at least ten years, in which he or she is the registered representative/holder of the farm; (4) must be in the possession of necessary agricultural machines and equipment. ${ }^{55}$

Under these conditions, the agricultural land in private ownership may be obtained by an EU national if it: (1) is not declared by special statute as a building plot; (2) cannot be considered a natural resource; (3) is not a military establishment or a protective strip around one. 56

\footnotetext{
${ }^{50}$ As for the complexity of legal issues arising from the acquisition of agricultural land in one EU country by the nationals of other member state of the EU, see especially: Szilágyi 2016, 1427-1451.; Szilágyi 2017, 1055-1072.

51 As for the adoption of the Agreement and its impact on the legal order of Serbia see especially: Stanivuković \& Đajić 2008, 391-412.

${ }^{52}$ Stabilisation and Association Agreement, Art. 63, s. 3.

${ }^{53}$ Law on Agricultural Land, Art. 72d.

${ }^{54}$ Ibid. Art. 72d, s. 1.

${ }^{55}$ Ibid. Art. 72 d, s. 2.

56 Ibid. Art. 72d, s. 3.
} 
Moreover, the law prescribes that the object of acquisition may not be any agricultural land located in the $10 \mathrm{~km}$-wide strip along the borders of Serbia, ${ }^{57}$ with the exception of agriculture land originating from the process of restitution of nationalised property. ${ }^{58}$

Even if these conditions are met, an EU national may not obtain more than two hectares of agricultural land. ${ }^{59}$

The Ministry of Agriculture determines if the statutory conditions are met. ${ }^{60}$

The law states explicitly that all three time periods are computed from the day of entry into force of the Law, that is, as of 1 September, 2017.61 This means that no EU national may obtain ownership on agricultural land prior to 1 September, 2027. Theoretically, this is the first day when the time period of 10 years of having a registered agricultural farm in Serbia may expire.

In addition, the Republic of Serbia has the right to pre-emption. ${ }^{62}$ This means that even if an EU national satisfies all statutory conditions, the Republic of Serbia may exercise its right to buy the agricultural land under the terms as offered to the EU national.

Finally, the Law states that a contract aimed at the acquisition of agricultural land by an EU national is deemed null and void if any of the statutory conditions are not met. ${ }^{63}$

A conclusion may be drawn that the amendments of the Law on Agricultural Land from August 2017 do not explicitly deprive legal persons from the EU from the possibility of obtaining ownership over agricultural land. However, only natural persons who are nationals of a member state of the EU may appear as buyers as legal persons cannot have family farms, nor can a legal person be registered as the representative of a family farm. Even the possibility of acquiring ownership of agricultural land by EU citizens is a theoretical contingency rather than a real possibility. Until 1 September, 2027, no natural person who is a citizen of the EU may acquire agricultural land in ownership at all, but even after this date, the prospects of acquisition of ownership are still very slim.

\subsection{Establishing a domestic legal person as a means to circumvent the prohibition of the acquisition of agricultural land by foreigners}

The restrictions in respect to acquiring ownership of any real estate, including agricultural land, by foreign natural or legal persons can easily be circumvented by utilising the rules of company law. The effective Law on Companies has a highly liberalistic approach towards the issue of establishing companies by foreign natural persons or legal entities. In general, aside from some special branches, it imposes no

\footnotetext{
${ }^{57}$ Ibid. Art. 72d, s. 4.

${ }^{58}$ Ibid. Art. 72 đ, s. 7.

${ }^{59}$ Ibid. Art. 72d, s. 5.

${ }^{60}$ Ibid. Art. 72d, s. 6.

${ }^{61}$ Ibid. Art. 72d, s. 8.

${ }^{62}$ Ibid. Art. 72d, s. 9-12.

${ }^{63}$ Ibid. Art. 72d, s. 13.
} 
restrictions on establishing a domestic LLC, which is the most popular and frequently used form of company, with a cost of no more than 100 RSD (less than EUR 1), which is the minimal capital requirement of an LLC. ${ }^{64}$ Therefore, by establishing a domestic LLC with a negligible amount of capital, the foreign natural or legal person obtains a domestic subject of law, which is, in legal terms, fully capable of acquiring ownership of real estate, including agricultural land. The issue of acquisition of ownership of real estate by foreign natural and legal persons as members of the company would eventually surface again when the company is dissolved or liquidated. However, taking into account the low capital requirement of establishing an LLC and the relatively low costs of maintaining it, its members rarely choose to dissolve it.

The chain of owners of real estate, including agricultural land, may be followed by looking into the Real Estate Registry. For a considerable time, the registry of real estate was administered by the courts (in most of Serbia) in the form of land registries, following the Austrian model. After a two-decade-long transition, which varied in pace over the course of time, the administration of the registry of real estate was delegated from judicial to administrative competency: the Real Estate Registry now not only administers factual data about real estate but also contains data on ownership and other rights related to real estate as well.

With respect to legal persons, the Law on the Central Registry of Real Owners, adopted in 2018, prescribes the duty of all legal persons to register the natural person who is to be considered as the real or beneficiary owner of the legal entity. Per this legislative measure, even in the case of multiple, chainlike ownership relations among several companies, the natural person who stands at the end of the ownership chain must be registered.

\section{Conclusions}

Serbia profoundly relies on agriculture. Around $85 \%$ of the territory of Serbia is declared to be rural areas, where around $55 \%$ of the population lives and generates approximately $41 \%$ of the national GDP 65 , in which family farms play a major role. Family farms have always been considered the major propulsive force in the realisation of policy considerations with respect to agricultural and rural development, even in the era of Yugoslav socialism. Namely, the collectivisation of agricultural land in Yugoslavia was not as efficient as in other CEE countries, the consequence of which was that $75-80 \%$ of arable land remained in private ownership and was used by small family farms. ${ }^{66}$ The situation has not changed profoundly as of the present day. According to statistical data from 2018, more than $84 \%$ of the arable land in Serbia is cultivated by family farms, the members of which can only be natural persons. ${ }^{67}$ This means that less than $15 \%$ of agricultural land is in the possession of legal persons, even though there is no ownership or possession cap for either natural persons or legal entities on the one hand, and legal entities can, without restriction, access the market of agricultural land

\footnotetext{
${ }^{64}$ Law on Companies, Art. 145.

${ }^{65}$ Subić, Jeločnik \& Jovanović 2015, 15.

${ }^{66}$ Hartvigsen \& Gorgan 2020, 87.

${ }^{67}$ Statistical Office of the Republic of Serbia 2018.
} 
Attila Dudás

Legal Frame of Agricultural Land Succession and Acquisition by Legal Persons in Serbia
Journal of Agricultural and

Environmental Law

$30 / 2021$

on the other. Although land ownership and land use is predominantly concentrated in family farms, the system still faces profound challenges as both the fragmentation of ownership and the fragmentation of the use of agricultural land are considered high. ${ }^{68}$

Only registered agricultural farms/holdings can be beneficiaries of agricultural subsidies. The most privileged position among them is family farms, a category reserved for natural persons belonging to one family, living together and engaged in agricultural production.

The rules on the succession and transfer of agricultural land in Serbia may be characterised as liberalistic. There are no special inheritance regimes applicable specifically to the succession of agricultural land. There is only the possibility of a heir, engaged in agricultural production, to request that the court name him or her the sole heir of the agricultural land, with the obligation to compensate other heirs. Similarly, the transfer of agricultural land by inter vivos transaction is also essentially without any meaningful legal restrictions, either for natural or legal persons. There is no cap on the acquisition of ownership, nor must the buyer prove that he or she is, in fact, engaged in agricultural production. The Serbian market for agricultural land is much more advanced than that of other CEE countries. ${ }^{69}$ According to the model developed by Williamson et al. ${ }^{70}$, which distinguishes five stages in the development of the market of agricultural land, according to Hartvigsen and Gorgan, no CEE country has reached stage five, while only five have reached stage four, including Serbia. ${ }^{71}$ In stage four, the land market becomes more mature, and the number of transactions is growing. ${ }^{72}$

The Serbian law excludes the possibility of acquisition of ownership of agricultural land by foreign natural persons or legal entities. According to the Stabilisation and Association Agreement concluded with the European Union, it was expected that Serbia would gradually enable natural persons and legal entities from the member states of the EU to acquire ownership of agricultural land no later than by 1 September, 2017, when the four-year period for the implementation of the aforementioned obligation expired. Seemingly with the aim of meeting this obligation, the Serbian National Assembly amended the Law on Agricultural Land in August 2017. The amendments explicitly regulate under which conditions natural and legal persons from the EU may acquire ownership of agricultural land. However, even a superficial reading of the new regulation reveals that the opposite effect has been achieved. Instead of enabling natural and legal persons from the EU to obtain ownership of agricultural land on equal footing with their domestic counterparts, the legislator created a set of special conditions applicable only to the former but not to the latter. Moreover, the conditions are so strict that no legal person could meet them, while natural persons only hypothetically could do so, if at all. Therefore, it seems that the 2017 amendments to the Law on Agricultural Land can hardly be said to have the aim of implementing the Stabilisation and Association Agreement. ${ }^{73}$

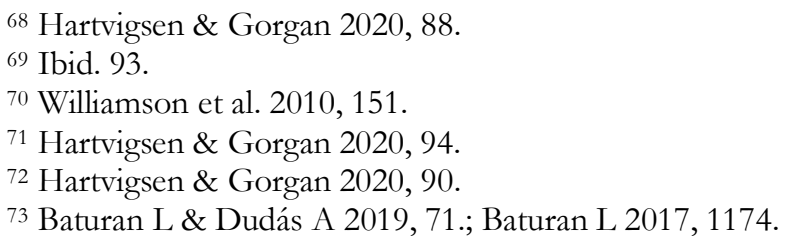




\section{Bibliography}

1. Avsec F (2020) The preemption right on agricultural land in Slovenia: Environmental Law past developments and future challenges, Journal of Agricultural and Environmental Law 15(28), pp. 9-36, doi: https://doi:10.21029/JAEL.2020.28.9

2. Baturan L \& Dudás A (2019) Legal Regime of Agricultural Land in Serbia with Special Regard to the Right of Foreigners to Acquire Ownership, CEDR Journal of Rural Law (1), 63-71

3. Baturan L (2017) Pravo stranih lica da stiču svojinu na poljoprivrednom zemljištu u Srbiji nakon zakonskih novela iz 2017. Godine [Right of foreigners to acquire property on agricultural land in Serbia after law on agricultural land amendments from 2017], Zbornik Pravnog fakulteta u Novom Sadu (3-2), pp. 1153-1175, doi: $10.5937 /$ zrpfns $51-15238$

4. Csák Cs \& Szliágyi J E (2013) Legislative tendencies of land ownership acquisition in Hungary, Agrarrecht Jahrbuch, pp. 215-233.

5. Hartvigsen M \& Gorgan M (2020) FAO Experience with Land Market Development and Land Management Instruments in Eastern Europe and Central Asia, Journal of Agricultural and Environmental Law 15(29), pp. 85-103, doi: https://doi.org/10.21029/JAEL.2020.29.85

6. Kulauzov M (2008) Položaj žena u porodičnoj zadruzi prema običajnom pravu južnih Slovena [The Status of Women in the Extended Family Group according to Customary Law of South Slavs], Zbornik Pravnog fakulteta u Novom Sadu (1-2), pp. 807-816, doi:10.5937_zrpfns42-0046.pdf

7. Kulauzov M (2010) Pravila običajnog prava o deobama porodičnih zadruga južnih slovena [Customary Law on the Division of Extended Family Groups of South Slavs], Zbornik Pravnog fakulteta u Novom Sadu (2), pp. 281-289, doi: 10.5937_zrpfns44-0031.pdf

8. Milošević G, Kulić M, Đurić Z \& Đurić O (2020) The Taxation of Agriculture in the Republic of Serbia as a Factor of Development of Organic Agriculture, Sustainability (12), pp. 1-17, doi: 10.3390/su12083261

9. Olajos I (2017) The acquisition and the right of use of agricultural lands, Environmental Law in particular the developing Hungarian court practice, Journal of Agricultural and Environmental Law 12(23), pp. 91-103, doi: https://doi:10.21029/JAEL.2017.23.91

10. Raisz A (2017) Topical issues of the Hungarian land-transfer law: Purchasing and renting agricultural land: Legal framework and practical problems, CEDR Journal of Rural Law (3), pp. 68-74.

11. Stanivuković M \& Đajić S (2008) Sporazum o stabilizaciji i pridruživanju i Prelazni trgovinski sporazum Srbije i Evropskih zajednica - pravno dejstvo i značaj [Stabilisation and Association Agreement and Interim Trade Agreement between Serbia and the European Community - legal effect and relevance], Zbornik Pravnog fakulteta u Novom Sadu (1-2), pp. 391-412. 


\section{Attila Dudás}

Legal Frame of Agricultural Land Succession and

Acquisition by Legal Persons in Serbia
Journal of Agricultural and

Environmental Law

$30 / 2021$

12. Subić J, Jeločnik M \& Jovanović M (2015) Importance of Family Agricultural Holdings in Sustainable Development of Rural Areas in Serbia, Proceedings from International scientific and practical conference - Development of entrepreneurship: New horizons. Stavropol State Agrarian University, Faculty of social and cultural service and tourism, Stavropol, Russia, pp. 14-19.

13. Szilágyi J E (2016) Acquisition of the ownership of agricultural lands in Hungary, taking the EU's and other countries' law into consideration, Zbornik Pravnog fakulteta u Novom Sadu (4), pp. 1437-1451, doi: 10.5937/zrpfns50-12226

14. Szilágyi J E (2017) Cross-border acquisition of the ownership of agricultural lands and some topical issues of the Hungarian law, Zbornik Pravnog fakulteta u Novom Sadu (3), pp. 1055-1072, doi: 10.5937/zrpfns51-13620

15. Szilágyi J E, Csák Cs, Olajos I \& Orosz F (2019) The topical situation and issues of agricultural law in Hungary, CEDR Journal of Rural Law (5), pp. 40-50.

16. Williamson I, Enemark S, Wallace J \& Rajabifard A (2010) Land Administration for Sustainable Development, ESRI Press Academic, Redlands, California.

17. Živković M (2015) Acquisition of Ownership of Real Property by Contract in Serbian Law - Departing from the Titulus-Modus System?, Annals of Faculty of Law in Belgrade - Belgrade Law Review (3), pp. 112-126. 